\section{Mechanical Harvesting and Irrigation Strategy Responses on 'Arbequina' Olive Oil Quality}

\author{
Josep Rufat ${ }^{1,5}$, Agustí J. Romero-Aroca ${ }^{2}$, Amadeu Arbonés ${ }^{1}$, \\ Josep M. Villar ${ }^{3}$, Juan F. Hermoso ${ }^{2}$, and Miquel Pascual ${ }^{4}$
}

ADDITIONAL INDEX wORDs. fatty acids, Olea europaea, sensory analysis, stability, superintensive orchard

SUMMARY. This study describes the effects of mechanical harvesting and irrigation on quality in 'Arbequina' olive oil (Olea europaea L.). Irrigation treatments included a control, deficit irrigation (DI) during pit hardening, and subsurface deficit irrigation (SDI). Results showed that mechanical harvesting damaged the olives and reduced olive oil quality by increasing free fatty acids (FFAs) and peroxide value, and by decreasing fruitiness, stability, bitterness, and pungency. DI resulted in increased fruit dry weight and oil content, which could be explained by their reduced crop load $(9.3 \%$ of crop reduction for DI and $23.9 \%$ for SDI). DI did not affect olive oil characteristics, whereas SDI increased stability, fruitiness, and bitterness, and decreased polyunsaturated fatty acid (PUFAs). In conclusion, mechanical harvesting tended to damage the fruit, resulting in lower quality olive oil, the DI strategy neither affected fruit nor olive oil characteristics, whereas the SDI strategy positively affected oil quality when greater water restrictions were applied.

I $\mathrm{n}$ recent years, the increasing consumption of olive oil has boosted the planting of intensive and superintensive orchard systems to achieve competitive production costs (Arbonés et al., 2014). Continuous mechanical harvesting is a key management practice in intensive and superintensive groves. Some studies have shown that this mechanical operation may cause internal fruit damage, leading to a fast reduction of quality in several varieties (Dag et al., 2008; Morales-Sillero and García, 2015; Yousfi et al., 2012). However, other researchers have reported that early harvesting and improving fruit management through mechanization

This study was supported by project PET2008-0248, Compo Expert Spain S.L., Applus Agroambiental S. A., Lab. Ferrer S.L., and Aceites Borges Pont SAU.

We gratefully acknowledge the Official Tasting Panel of Virgin Olive Oils of Catalunya for the sensory evaluation of samples.

${ }^{1}$ Ús Eficient de l'Aigua, IRTA, Parc Científic i Tecnològic Agroalimentari de Lleida, Parc de Gardeny Edifici Fruitcentre, E-25003 Lleida, Spain

${ }^{2}$ Olivicultura, Elaiotècnia i Fruita Seca, Institut de Recerca i Tecnologia Agroalimentàries (IRTA), Ctra. Reus-El Morell, km 3.8, E-43120 Constantí, Spain

${ }^{3}$ Departament de Medi Ambient i Ciències del Sòl, Universitat de Lleida, Av. Rovira Roure, 191, E-25198 Lleida, Spain

${ }^{4}$ Departament d'Hortofruticultura, Botànica i Jardineria, Universitat de Lleida, Av. Rovira Roure, 191, E-25198 Lleida, Spain

${ }^{5}$ Corresponding author. E-mail: josep.rufat@irta.cat.

https://doi.org/10.21273/HORTTECH04016-18 result in a better oil quality (Camposeo et al., 2013).

The success of superhigh-density orchards relies on the availability of the required amount of irrigation water, which is a scarce resource in many areas. In terms of crop management, DI strategies have demonstrated their feasibility for yield improvement in arid and semiarid areas (Gómezdel-Campo et al., 2014; Palese et al., 2010). Emerging irrigation technologies such as subsurface irrigation can also optimize water efficiency by reducing soil evaporation-a promising water-saving strategy (Rufat et al., 2014). Nevertheless, the optimal degree of water restriction should be assessed carefully to avoid an impairment of yield and quality (Girona et al., 2002) or even a reduction in the following year's blooming (Alegre et al., 2002).

It is well known that irrigation modulates plant water stress and affects olive fruit ripening as well as oil yield and quality. Hernández et al. (2009) reported that fatty acid composition of 'Arbequina' and 'Picual' depends on the expression of three genes that are related to external factors, including water supply. In addition, Vossen et al. (2008), working on an irrigation trial with 'Arbequina' in California, reported an increase of PUFAs and a reduction in monounsaturated fatty acids (MUFAs) when irrigation increased, which is in agreement with the results of Tovar et al. (2001) who studied 'Arbequina' under different irrigation conditions in Catalonia. However, this was not observed in 'Frantoio', which was irrigated using a subsurface system at any of the irrigation doses used (Caruso et al., 2014).

Several studies suggest that olive oil composition depends on both irrigation and the ripening process. In this sense, total polyphenol content is related to such factors, increasing olive oil bitterness and oil stability (Motilva et al., 2000; Tovar et al., 2001) as well as flavor composition (Caporaso, 2016). Caruso et al. (2014), analyzed the effects of irrigation on the lipoxygenase pathway compounds and reported a significant increase of alcohol and ester volatiles in greater irrigation doses, suggesting a clear effect on sensory characteristics of olive oil, although no sensory analysis was performed to confirm that possibility.

Currently, there are few published studies that combine the effect of irrigation regime and harvest 
method as key techniques for production and quality management of superintensive crop growth of olive oil orchards in semiarid conditions. Therefore, this work aimed to study the impact of several of the most widespread irrigation strategies on 'Arbequina' olive oil quality, as well as the effects caused by mechanical harvesting in irrigated superintensive crop-growing conditions.

\section{Materials and methods}

EXPERIMENTAL SITE AND MANAGEMENT. The trial was conducted on a commercial adult 'Arbequina' olive plot in Torres de Segre (Lleida, Spain) during three consecutive years: 2010,2011 , and 2012. The climate is a continental Mediterranean-type, with an average rainfall of $350 \mathrm{~mm} /$ year, distributed irregularly. The trees were planted in Summer 2002 at $4.5 \times$ $2.2 \mathrm{~m}$, resulting in a density of 1010 trees/ha. The soil was moderately deep, calcareous with a $\mathrm{pH}$ of 8 , and had an organic matter content of $1.5 \%$, with a medium texture (loamy) and an electrical conductivity $(1: 5)$ of $2.82 \mathrm{dS} \cdot \mathrm{m}^{-1}$ (resulting from the presence of gypsum). The irrigation system consisted of autocompensated drip emitters every $60 \mathrm{~cm}$ and a water flow rate of $2.3 \mathrm{~L} \cdot \mathrm{h}^{-1}$, used for both surface and subsurface systems. Irrigation water came from the Segre River. Water conductivity was, on average, $0.9 \mathrm{dS} \cdot \mathrm{m}^{-1}$, with chloride at 2.25 meq. $\mathrm{L}^{-1}$, sodium at $2.14 \mathrm{meq} \cdot \mathrm{L}^{-1}$, boron less than $0.15 \mathrm{ppm}$, and nitrate less than 9 ppm.

The trial consisted of three replicates distributed in randomized blocks. Each elementary plot had 18 trees distributed in three adjacent rows, in which the four central trees were monitored.

Harvesting AND SAMpling. Mechanical harvesting was carried out by means of an over-the-row harvester (model Gl40 SW; Gregoire ${ }^{\circledR}$, Chateaubernard, France). The harvester passed over the four olive trees and the fruit were collected into a bin. Manual harvesting of samples were taken randomly the day before mechanical harvesting from the same four-tree plots. Sample size was $3 \mathrm{~kg}$ of fruit per plot and harvesting method. Fruit were transported just after harvest, stored in a cold room $\left(5{ }^{\circ} \mathrm{C}\right)$, and processed within the $12 \mathrm{~h}$ after harvest. Harvest dates were 25 Nov. 2010, 28 Nov. 2011, and 30 Nov. 2012.
IRRIGATION TREATMENTS. Three irrigation treatments were tested. The control treatment trees were fully irrigated during the whole season, according to the FAO methodology, based on the water balance (Allen et al., 1998). Trees under the DI strategy were irrigated as the control trees from March to June, but only $25 \%$ of the dose was subsequently applied to the control group during pit hardening (beginning of July until the beginning of September), followed by full irrigation from the beginning of September to the end of October. The SDI strategy consisted of applying 70\% of control requirements from March to June, 25\% from July to the beginning of September, and again $70 \%$ of total requirements until the end of October because of less soil evaporation. More details are reported in Rufat et al. (2014). All plots were fertilized weekly from May to October using $50 \mathrm{~kg} \cdot \mathrm{ha}^{-1}$ nitrogen $(\mathrm{N})$ with $\mathrm{N}-32$ solution ( $16 \%$ amide, $8 \%$ ammonium, 8\% nitrate; Compo Expert Spain, Barcelona, Spain) and $100 \mathrm{~kg} \cdot \mathrm{ha}^{-1}$ potassium $\left(\mathrm{K}_{2} \mathrm{O}\right)$ per year.

Olive OIL EXTRACTION. Fruit were processed using an Abencor system (MC2; Ingenierias y Sistemas, Seville, Spain). This method reproduces the industrial process at a laboratory scale, including a metallic hammer mill (6-mm crusher sieve), a thermo-beater at room temperature $\left(20^{\circ} \mathrm{C}\right)$ for $30 \mathrm{~min}$, a pulp centrifuge, an oil vertical centrifuge at $2000 \mathrm{rpm}$, and a natural decanter. Olive oil samples were put into dark glass bottles and split into two groups; one was preserved at $4{ }^{\circ} \mathrm{C}$ before sensory analysis ( 1 week after extraction) and the other was stored at $-20{ }^{\circ} \mathrm{C}$ until chemical analysis (1 month later).

Fruit characteristics, Olive OIL CONTENT, AND QUALITY ANALYSIS. Fruit maturity index (MI) was measured as proposed by Frías et al. (1991), moisture was analyzed in an oven $\left(105^{\circ} \mathrm{C}\right)$, and oil content was determined on the dried sample by nuclear magnetic resonance (MaranS60; Oxford Instruments, Abingdon, UK) and referred on the basis of dry fruit weight. Olive oil physicochemical analyses (FFAs, peroxide value, ultraviolet absorption characteristics at 232 and $270 \mathrm{~nm}$, and oil stability) were performed according to official methods (European Union Standard
Methods, 1991). The results are expressed as percentage of oleic acid, milliequivalents of active oxygen $\left(\mathrm{O}_{2}\right)$ per kilogram oil, and specific extinction coefficient at 232 and $270 \mathrm{~nm}$ ( $\mathrm{K}_{232}$ and $\mathrm{K}_{270}$, respectively). Stability was expressed as the oxidation induction time (in hours) measured according to Laübli and Bruttel (1986) using the Rancimat method (model Rancimat-679; Metrohm Co., Basel, Switzerland), analyzing $2.5 \mathrm{~g}$ of olive oil sample at $120^{\circ} \mathrm{C}$ with an air flow of $20 \mathrm{~L} / \mathrm{h}$. Fatty acid composition was determined by gas chromatography as fatty acid methyl esters, according to European Union Standard Methods (1991). Total phenol content was obtained using the method described by Vázquez-Roncero et al. (1973). An oil sample $(10 \mathrm{~g})$ was dissolved in $50 \mathrm{~mL}$ hexane and extracted with methanol/ water $(60: 40 \mathrm{v} / \mathrm{v}, 3 \times 10 \mathrm{~mL})$. The aqueous fractions were collected in a volumetric flask. Total phenols were measured colorimetrically at 725 $\mathrm{nm}$ after adding the Folin-Ciocalteau reagent to the extract.

The sensory analysis was carried out by the Official Tasting Panel of Virgin Olive Oils of Catalonia according to European Union Standard Methods (1991). This panel relies on ISO (International Organization for Standardization) 17025 accreditation and is recognized by the International Olive Oil Council. Each oil sample was analyzed by eight tasters who scored the official sensory descriptors using a 10-cm open scale anchored on zero. In addition, the presence of secondary sensory attributes was determined by the percentage of panelists able to perceive each odor note using an open generic profile (Guerrero et al., 2001; Romero-Aroca et al., 1999).

Data analysis. The data were subjected to analysis of variance, multivariate analysis of variance, mixed-model analysis, and principal component analysis (PCA) using SAS software (version 9.2; SAS Institute, Cary, NC).

\section{Results}

A P P L I E D W A T E R A N D EVAPOTRANSPIRATION REPOSITION BY IRRIGATION. The seasonal irrigation water for each irrigation treatment during the three crop seasons is shown in Table 1. Irrigation in the control treatment ranged from $338 \mathrm{~mm}$ in 2010 to $475 \mathrm{~mm}$ in 2011 , whereas 
Table 1. Total water applied in 2010, 2011 and 2012 cropping seasons and olive and oil yield for each irrigation treatment: control, deficit irrigation (DI), and subsurface deficit irrigation (SDI).

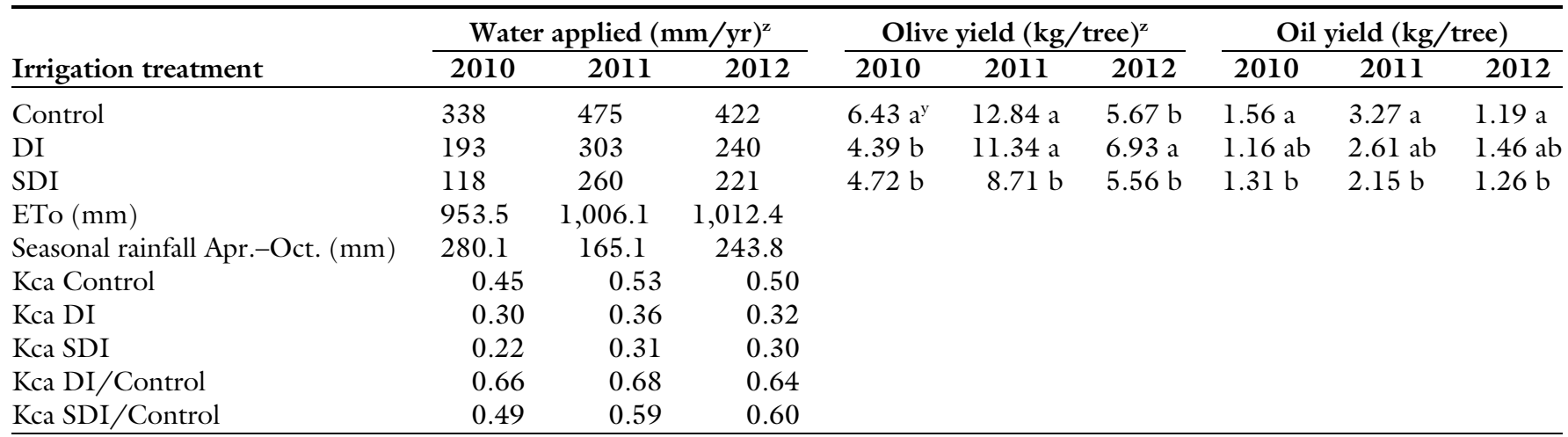

${ }^{\mathrm{z}} 1 \mathrm{~mm}=0.0394$ inch, $1 \mathrm{~kg}=2.2046 \mathrm{lb}$.

${ }^{\mathrm{y}}$ Means within a column followed by the same letter are not significantly different by Tukey's honest significant difference test at $P \leq 0.05$.

ETo $=$ reference evapotranspiration; $\mathrm{Kca}=$ actual crop coefficient.

Table 2. Significance of repeated-measurements model (multivariate analysis of variance) for olive production parameters and fruit characteristics (probability values), considering year as a repeated factor.

\begin{tabular}{lccccc}
\hline & Irrigation $^{\mathrm{z}}(P>\mathrm{F})$ & Block $^{\mathrm{z}}(\boldsymbol{P}>\mathrm{F})$ & Year $(P>\mathrm{F})$ & Year $\times$ irrigation $^{\mathrm{y}}(P>\mathrm{F})$ & ${\text { Year } \times \text { block }^{\mathrm{y}}(P>\mathrm{F})}^{*}$ \\
\hline Olive yield & $<0.001^{*}$ & 0.696 & $<0.001^{*}$ & 0.148 & 0.274 \\
Oil yield & $0.004^{*}$ & 0.777 & $<0.001^{*}$ & 0.392 & 0.301 \\
Maturity index & 0.332 & 0.319 & $0.011^{*}$ & $0.028^{*}$ & 0.233 \\
Fruit fresh weight & 0.254 & 0.121 & $0.034^{*}$ & 0.076 & 0.395 \\
Fruit dry weight & $0.001^{*}$ & $0.019^{*}$ & $0.002^{*}$ & 0.181 & 0.074 \\
Pit weight & 0.220 & 0.395 & $0.001^{*}$ & $0.024^{*}$ & 0.296 \\
Flesh/pit ratio & 0.119 & 0.074 & 0.191 & 0.139 & 0.206 \\
Oil content & $0.002^{*}$ & 0.380 & $0.001^{*}$ & 0.166 & 0.458 \\
Fruit water content & 0.738 & 0.437 & $0.007^{*}$ & 0.343 & 0.402 \\
\hline
\end{tabular}

${ }^{\mathrm{z}}$ According to the $\mathrm{F}$ test.

${ }^{y}$ According to Roy's max root criteria.

*Denotes a significant effect or interaction at $P \leq 0.05$.

Table 3. Average olive yield, oil content, and fruit characteristics related to irrigation treatments: control, deficit irrigation (DI), and subsurface deficit irrigation (SDI).

\begin{tabular}{lccr}
\hline & \multicolumn{3}{c}{ Irrigation treatment } \\
\cline { 2 - 4 } & Control & DI & \multicolumn{1}{c}{ SDI } \\
\cline { 2 - 4 } & \multicolumn{3}{c}{$($ mean \pm SD) } \\
\hline Olive yield $(\mathrm{kg} / \text { tree })^{\mathrm{z}}$ & $9.26 \pm 4.22 \mathrm{a}^{\mathrm{y}}$ & $9.14 \pm 2.99 \mathrm{a}$ & $7.14 \pm 2.50 \mathrm{~b}$ \\
Oil yield $(\mathrm{kg} /$ tree $)$ & $2.14 \pm 1.10 \mathrm{a}$ & $2.13 \pm 1.11 \mathrm{~b}$ & $1.76 \pm 1.07 \mathrm{~b}$ \\
Oil content $(\%$ dry basis $)$ & $48.00 \pm 0.59 \mathrm{~b}$ & $49.30 \pm 0.67 \mathrm{ab}$ & $51.10 \pm 0.43 \mathrm{a}$ \\
Maturity index & $2.07 \pm 0.36$ & $1.95 \pm 0.16$ & $2.15 \pm 0.56$ \\
Fruit fresh weight $(\mathrm{g})^{\mathrm{z}}$ & $1.70 \pm 0.10$ & $1.78 \pm 0.10$ & $1.84 \pm 0.11$ \\
Fruit dry weight $(\mathrm{g})$ & $0.82 \pm 0.04 \mathrm{~b}$ & $0.84 \pm 0.05 \mathrm{ab}$ & $0.89 \pm 0.04 \mathrm{a}$ \\
Pit weight $(\mathrm{g})$ & $0.41 \pm 0.03$ & $0.46 \pm 0.03$ & $0.44 \pm 0.02$ \\
Flesh/pit ratio $\left(\mathrm{g} \cdot \mathrm{g}^{-1}\right)$ & $4.16 \pm 0.14$ & $3.90 \pm 0.11$ & $4.22 \pm 0.15$ \\
Fruit water content $(\%)$ & $51.60 \pm 1.69$ & $52.50 \pm 1.98$ & $50.80 \pm 1.83$ \\
\hline
\end{tabular}

${ }^{\mathrm{z}} \mathrm{l} \mathrm{kg}=2.2046 \mathrm{lb}, \mathrm{l} \mathrm{g}=0.0353 \mathrm{oz}$.

${ }^{\mathrm{y}}$ Means within a column followed by the same letter are not significantly different by Tukey's honest significant difference test at $P \leq 0.05$.

irrigation decreased to $64 \%$ and $68 \%$ in the DI treatment, and to $49 \%$ and $60 \%$ in the SDI treatment for the same 2 years in comparison with control trees. Seasonal rainfall was scarce ( 165 to $250 \mathrm{~mm}$ ) and effective rainfall was negligible compared with reference evapotranspiration (ETo; effective rainfall range, 55-90 $\mathrm{mm}$ ). Actual crop coefficient (Kca) was calculated as (Irrigation + Effective rainfall)/ ETo, reaching maximum values for the control treatment (about 0.5 ) and descending to 0.30 and 0.36 for DI, and even lower for SDI (0.22 and 0.31$)$. Water savings were obtained using the deficit irrigation strategies: $35 \%$ in DI and $44 \%$ in SDI.

FRUIT TRAITS AND YIELD COMPONENTS. The multivariate analysis of variance on repeated measurements (when year was the repeated factor) showed significant differences as the result of irrigation treatment and year effects on global fruit traits (Table 2). Deficit irrigation strategies tended to produce larger fruit that were richer in oil than those from the control treatment (Table 3). Pit weight, flesh-to-pit ratio, and fruit water content showed no significant differences between irrigation strategies. Within years, fruit were harvested at the same MI, without significant differences between treatments. However, when yield was greater (year 2011), fruit of deficit irrigation strategies exhibited a greater MI than control fruit. On the other hand, total crop load correlated inversely to fruit weight $(r=-0.631$, 
$P=0.001)$, pit weight $(r=-0.717$, $P<0.001)$, dry fruit weight $(r=$ $-0.692, P<0.001)$, and MI $(r=$ $-0.60, P=0.001)$.

FATTY ACID COMPOSITION. The irrigation strategies affected the fatty acid composition of the olive oil (Table 4). Average PUFAs were significantly less using the SDI strategy ( $11.9 \%$ vs. $13.2 \%$ in DI and $12.9 \%$ in control), affecting both linoleic (C18:2) and linolenic (C18:3) acids. MUFAs showed no significant differences between treatments, because oleic acid (C18:1) averaged $65 \%$ in all treatments, whereas palmitoleic acid $(\mathrm{Cl} 6: 1)$ was $1.4 \%$ in SDI, $1.6 \%$ in DI, and $1.8 \%$ in control treatments. No significant interaction between irrigation strategy and year was observed with respect to fatty acids composition (Table 4).

Olive OIL PHYSICOCHEMICAL CHARACTERISTICS. FFAs were related significantly to harvesting system and year particularities (Table 4 ), without significant changes resulting from irrigation strategies. Mechanical harvesting increased FFAs from $0.12 \%$ to $0.18 \%$ on average (Table 5 ), although such a variation is not relevant from the official regulation point of view (COI/T.15/NC No 3/REV.10Trade Standard Applying to Olive Oils and Olive-Pomace oils. 2015). In addition, peroxide value did not change between irrigation strategies, but significant differences were observed with respect to harvesting method and year (Table 4). In fact, mechanical harvesting increased peroxides by at least 2 meq. $\mathrm{kg}^{-1} \mathrm{O}_{2}$ compared with the manual system (Table 5). Polyphenol content was also affected by harvesting method and irrigation, decreasing when olives were harvested mechanically and when irrigation rate increased. Year effect on polyphenols was related to changes in MI (1.8 in 2011 and 2.6 in 2012), suggesting other complementary effects that could be related to annual variations in crop load and $\mathrm{Kca}$. Olive oil stability was affected by harvesting system, irrigation, and year conditions, without significant interactions among these factors (Table 4). Mechanical harvesting resulted in a significant reduction of stability from 11.9 to $8.3 \mathrm{~h}$, which is a relevant variation for quality in 'Arbequina' oil. As for irrigation, the SDI strategy promoted greater stability ( $45 \%$ more) than the other treatments (SDI scored
$12.9 \mathrm{~h}$; DI, $8.6 \mathrm{~h}$; and control, $8.9 \mathrm{~h}$ ) (Table 5).

SENSORY CHARACTERISTICS. Harvesting method strongly affected sensory characteristics. Mechanical harvesting resulted in olive oil lower in fruitiness, cut grass perception, bitterness, pungency, and astringency, whereas sweetness was always greater (Table 5). In addition, a significant harvest system-by-year interaction was observed for all descriptors (Table 6). This can be explained as the result of crop load and MI, with increasing susceptibility to damage when fruit were larger and more mature. In 2012, which demonstrated a low fruit yield (Table 1 ), fruit were larger and riper, and the differences resulting from the harvesting systems were greatest. Irrigation treatment affected the sensory profile significantly (Table 6). Deficit irrigation strategies resulted in oils more pungent, bitter, and astringent than control oil (Table 5). This response is in accordance with a significant increase in total phenols when irrigation was restricted. Also, olfactory attributes changed significantly between irrigation treatments, with oils with more fruitiness and cut grass perception obtained when deficit irrigation was applied. However, the irrigationby-year effect was significant for fruitiness and cut grass perception in the sense that differences in intensity of these attributes between control and deficit treatments were greater in the year with a lesser water supply, as would be expected. On the other hand, the irrigation-by-harvest system interaction was only significant for the cut grass attribute, with a greater reduction in the control irrigation level.

\section{Discussion}

Interpretation of the effects of the treatments (harvest method, irrigation strategy, and year) on the studied variables was carried out by PCA. After a preliminary analysis, the most relevant variables in the first two PCA components were closely related to harvest method and irrigation strategies-namely, the oil sensory characteristics, peroxides, polyphenols, fatty acid composition, and, to a lesser extent, yield and MI. The biplot of loadings, in the space defined by the first two principal components, explains $67.4 \%$ of the overall variance of results (Fig. 1). The first

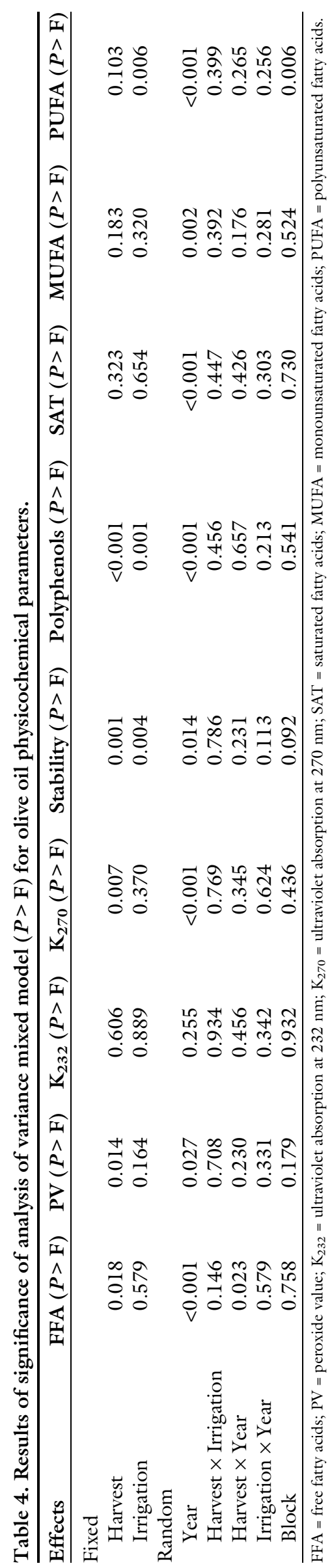

Horllechnology • October 2018 28(5) 
Table 5. Physicochemical characteristics of olive oil and sensory scores of oil related to irrigation [control, deficit irrigation (DI), and subsurface deficit irrigation (SDI)] and harvesting method treatments.

\begin{tabular}{|c|c|c|c|c|c|c|}
\hline \multirow{4}{*}{$\begin{array}{l}\text { Physicochemical } \\
\text { characteristic }\end{array}$} & \multicolumn{6}{|c|}{ Irrigation } \\
\hline & \multicolumn{2}{|c|}{ Control } & \multicolumn{2}{|c|}{ DI } & \multicolumn{2}{|c|}{ SDI } \\
\hline & \multicolumn{6}{|c|}{ Harvesting } \\
\hline & Manual & Mechanical & Manual & Mechanical & Manual & Mechanical \\
\hline & \multicolumn{6}{|c|}{$($ mean $\pm S D)$} \\
\hline FFA (\% oleic acid) & $0.13 \pm 0.02$ & $0.18 \pm 0.02$ & $0.12 \pm 0.02$ & $0.18 \pm 0.02$ & $0.15 \pm 0.02$ & $0.17 \pm 0.02$ \\
\hline Palmitic acid Cl6:0 (\%) & $19.59 \pm 3.22$ & $16.24 \pm 1.61$ & $19.26 \pm 4.19$ & $17.61 \pm 2.26$ & $20.01 \pm 4.09$ & $17.03 \pm 1.49$ \\
\hline Oleic acid C18:1 (\%) & $63.82 \pm 1.29$ & $66.07 \pm 1.59$ & $64.3 \pm 1.83$ & $65.02 \pm 1.00$ & $64.42 \pm 2.23$ & $66.82 \pm 1.08$ \\
\hline Linoleic acid C18:2 (\%) & $11.69 \pm 1.99$ & $12.82 \pm 1.13$ & $12.42 \pm 1.99$ & $12.55 \pm 1.48$ & $11.25 \pm 1.54$ & $11.49 \pm 0.99$ \\
\hline Linolenic acid C18:3 (\%) & $0.62 \pm 0.19$ & $0.69 \pm 0.15$ & $0.72 \pm 0.18$ & $0.7 \pm 0.14$ & $0.57 \pm 0.15$ & $0.58 \pm 0.09$ \\
\hline Saturated & $21.62 \pm 3.59$ & $18.13 \pm 1.81$ & $21.15 \pm 4.41$ & $19.60 \pm 2.37$ & $18.58 \pm 9.16$ & $18.98 \pm 1.72$ \\
\hline MUFA & $65.83 \pm 1.70$ & $67.92 \pm 1.56$ & $65.92 \pm 2.08$ & $66.62 \pm 1.17$ & $65.75 \pm 2.46$ & $68.22 \pm 1.19$ \\
\hline $\mathrm{K}_{270}$ & $0.10 \pm 0.00$ & $0.10 \pm 0.01$ & $0.10 \pm 0.00$ & $0.09 \pm 0.01$ & $0.12 \pm 0.01$ & $0.10 \pm 0.01$ \\
\hline Stability (h at $120^{\circ} \mathrm{C}$ ) & $10.8 \pm 0.56 \mathrm{Ba}^{\mathrm{y}}$ & $7.00 \pm 0.89 b$ & $10.40 \pm 0.55 \mathrm{Ba}$ & $6.87 \pm 0.97 b$ & $14.64 \pm 1.04 \mathrm{Aa}$ & $11.12 \pm 1.46 \mathrm{~b}$ \\
\hline Polyphenols $\left(\mathrm{mg} \cdot \mathrm{kg}^{-1}\right)^{\mathrm{z}}$ & $108.2 \pm 17.3 \mathrm{Ba}$ & $95.2 \pm 12.3 \mathrm{~b}$ & $130.9 \pm 16.4 \mathrm{Ba}$ & $106 \pm 18.3 b$ & $126 \pm 17.1 \mathrm{Aa}$ & $110.2 \pm 15.7 b$ \\
\hline Fruitiness & $5.73 \pm 0.15 \mathrm{Ba}$ & $4.57 \pm 0.56 b$ & $5.84 \pm 0.24 \mathrm{Ba}$ & $4.75 \pm 0.52 b$ & $6.18 \pm 0.09 \mathrm{Aa}$ & $5.75 \pm 0.25 b$ \\
\hline Bitterness & $3.70 \pm 0.16 \mathrm{Ba}$ & $2.67 \pm 0.37 b$ & $3.72 \pm 0.21 \mathrm{Ba}$ & $2.98 \pm 0.35 \mathrm{~b}$ & $4.72 \pm 0.27 \mathrm{Aa}$ & $4.32 \pm 0.35 b$ \\
\hline Pungency & $4.21 \pm 0.10 \mathrm{Ba}$ & $3.55 \pm 0.48 b$ & $4.84 \pm 0.22 \mathrm{ABa}$ & $4.05 \pm 0.42 \mathrm{~b}$ & $5.22 \pm 0.18 \mathrm{Aa}$ & $4.92 \pm 0.24 b$ \\
\hline Astringency & $2.06 \pm 0.17 \mathrm{Ba}$ & $1.18 \pm 0.46 \mathrm{~b}$ & $2.31 \pm 0.15 \mathrm{Ba}$ & $1.33 \pm 0.37 b$ & $2.83 \pm 0.29 \mathrm{Aa}$ & $2.65 \pm 0.29 b$ \\
\hline Cut grass & $3.54 \pm 0.13$ & $1.92 \pm 0.73$ & $3.58 \pm 0.22$ & $2.16 \pm 0.60$ & $3.94 \pm 0.12$ & $3.48 \pm 0.22$ \\
\hline Sweetness & $4.63 \pm 0.18 \mathrm{Ab}$ & $4.90 \pm 0.15 \mathrm{a}$ & $4.55 \pm 0.13 \mathrm{Ab}$ & $5.03 \pm 0.15 \mathrm{a}$ & $4.27 \pm 0.19 \mathrm{~B}$ & $4.28 \pm 0.19$ \\
\hline
\end{tabular}

${ }^{\mathrm{z}} \mathrm{l} \mathrm{kg}=2.2046 \mathrm{lb},\left(1.8 \times{ }^{\circ} \mathrm{C}\right)+32={ }^{\circ} \mathrm{F}, 1 \mathrm{mg} \cdot \mathrm{kg}^{-1}=1 \mathrm{ppm}$.

${ }^{y}$ Uppercase letters indicate differences between irrigation treatments. Lowercase letters indicate differences between harvesting systems according to Tukey's honest significant difference test $(P<0.05)$. When interactions were significant (Table 4$)$, no mean differences test was done for main effects.

$\mathrm{FFA}=$ free fatty acids; MUFA = monounsaturated fatty acids; $\mathrm{PUFA}=$ polyunsaturated fatty acids; $\mathrm{K}_{232}=$ ultraviolet absorption at $232 \mathrm{~nm} ; \mathrm{K}_{270}=\mathrm{ultraviolet}$ absorption at $270 \mathrm{~nm}$.

Table 6. Results of significance of analysis of variance mixed model for olive oil sensory attributes.

\begin{tabular}{|c|c|c|c|c|c|c|}
\hline Model & Fruitiness & Cut grass & Bitterness & Pungency & Sweetness & Astringency \\
\hline$P>\mathrm{F}$ & $<0.001$ & $<0.001$ & $<0.001$ & $<0.001$ & 0.005 & $<0.001$ \\
\hline$R^{2}$ & 0.831 & 0.871 & 0.812 & 0.831 & 0.610 & 0.822 \\
\hline Harvest & $<0.001$ & $<0.001$ & $<0.001$ & 0.007 & 0.036 & 0.003 \\
\hline Irrigation & 0.001 & 0.006 & $<0.001$ & $<0.001$ & 0.001 & $<0.001$ \\
\hline Year & $<0.001$ & 0.002 & $<0.001$ & $<0.001$ & 0.395 & 0.002 \\
\hline Irrigation $\times$ Year & 0.042 & 0.031 & 0.204 & 0.721 & 0.715 & 0.476 \\
\hline Block & 0.169 & 0.068 & 0.006 & 0.002 & 0.065 & 0.007 \\
\hline
\end{tabular}

component $(54.2 \%$ of total variance) is clearly associated with overlapping effects of harvest method and irrigation strategy. The observed association between irrigation strategies and fruit weight and yield can be explained by the differences in crop load (Fig. 2). In fact, crop load in SDI was less than control, imposing a significant yield limitation. This can be explained in terms of physiologic production cost or oil yield per unit of water used. Fruit water cost (or water productivity) was less in the control treatment $\left(4.3 \mathrm{~kg} \cdot \mathrm{mm}^{-1}\right)$ than in the DI $\left(6.6 \mathrm{~kg} \cdot \mathrm{mm}^{-1}\right)$ and SDI treatments $\left(7.6 \mathrm{~kg} \cdot \mathrm{mm}^{-1}\right)$, as reported by Rufat et al., (2014), indicating the well-known plant adaptive behavior to water status progressively reducing crop load in response to water reduction. This is in agreement with the results obtained by Serman et al. (2011), who worked on 'Arbequina' in superhigh-density orchards in Argentina, and with Dabbou et al. (2011), who studied irrigation doses in 'Koroneiki' in Tunisia.

Regarding harvest method effects, the increase in FFAs and peroxide value observed in the mechanically harvested fruit suggests significant damage to the olives. The same effect was reported by Yousfi et al. (2012), who compared manual harvesting with mechanical over-the-row harvesting in 


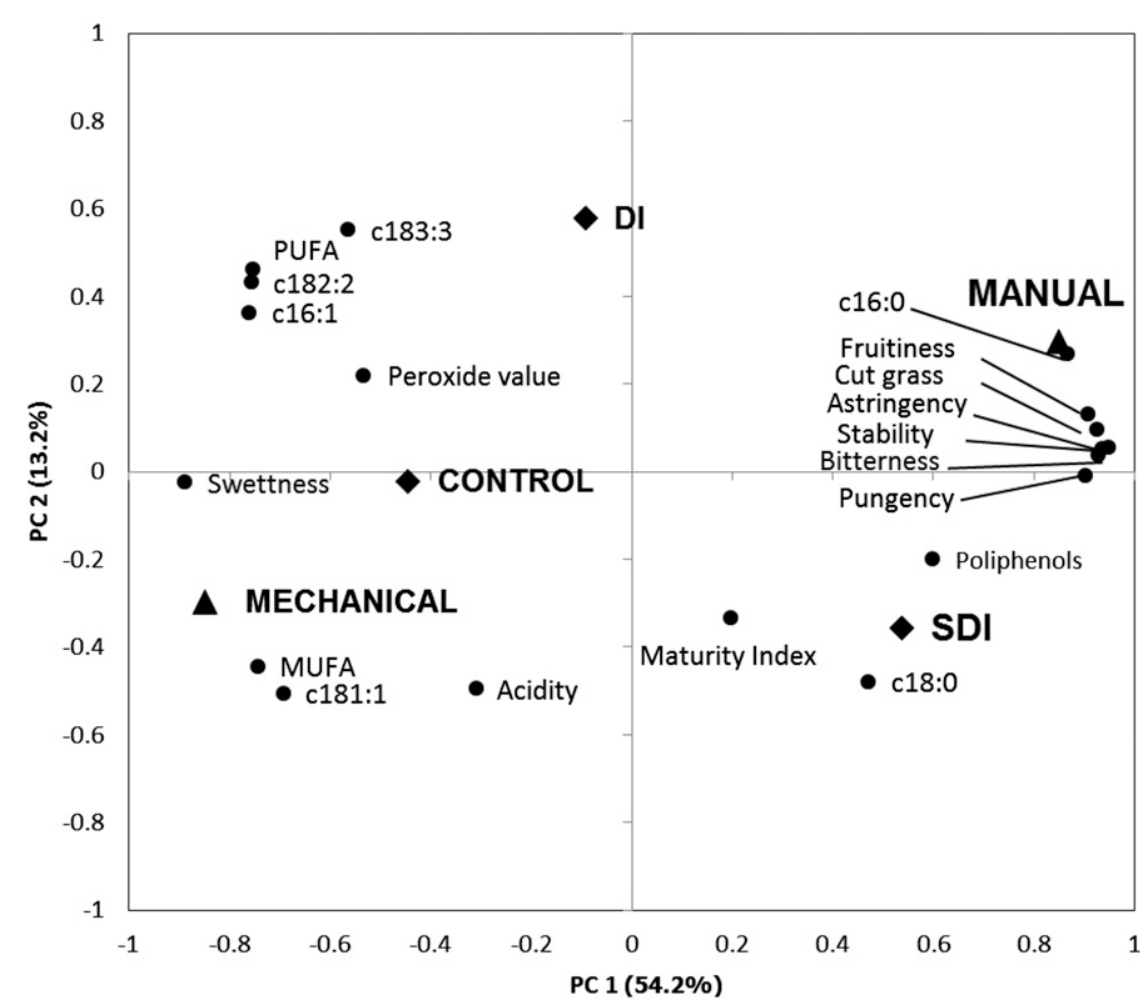

Fig. 1. Biplot of two first principal components (PC 1 and PC 2) analysis of selected variables for olive oil physicochemical and sensory analysis. Principal component analysis includes harvest method and irrigation treatments [control, deficit irrigation (DI), and subsurface deficit irrigation (SDI)]. PUFA, polyunsaturated fatty acids; MUFA, monounsaturated fatty acids.

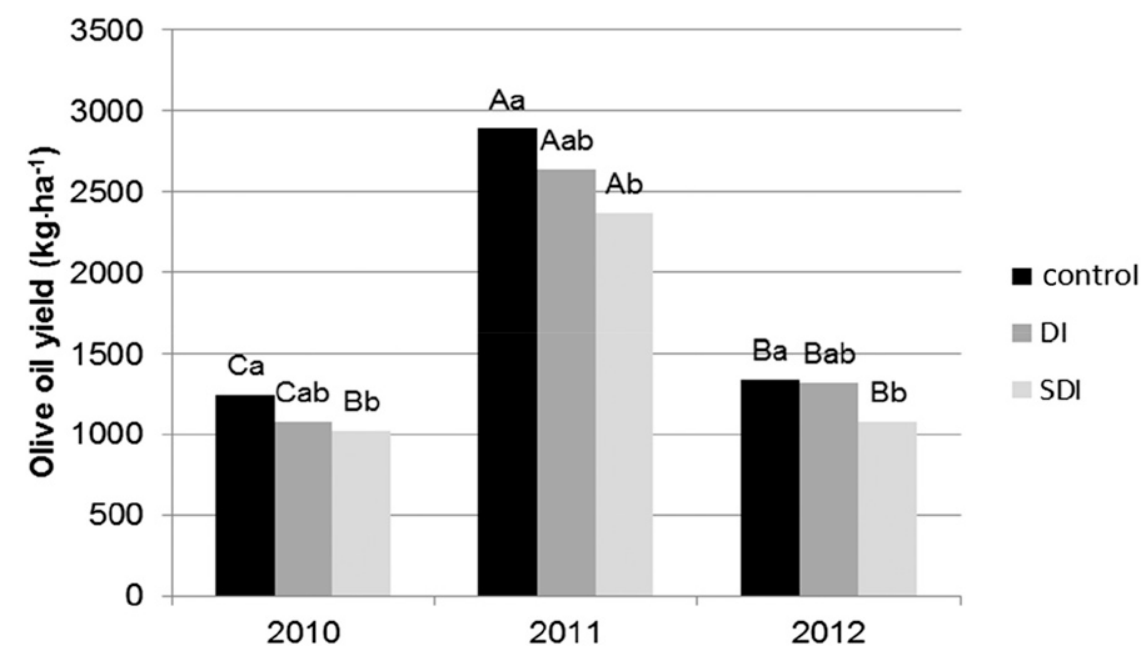

Fig. 2. Olive oil yield for the different irrigation strategies [control, deficit irrigation (DI), and subsurface deficit irrigation (SDI)] and years. Uppercase letters indicate differences between years within each irrigation level $(P<0.05)$. Lowercase letters indicate irrigation effects within each year $(P<0.05) ; 1 \mathrm{~kg} \cdot \mathrm{ha}^{-1}=$ $0.8922 \mathrm{lb} /$ acre.

'Arbequina' under superhigh-density system conditions. Mechanical harvest caused fruit damage, with the fruit sustaining rapid deterioration, losing polyphenols and stability. These trends are in agreement with the results obtained by Dag et al. (2012), who reported a shorter shelf life for oils from mechanically harvested fruit. Because of fruit damage, sensory quality was affected too, resulting in oils with lesser fruitiness and bitterness. Other research (Vichi et al., 2009 ) reported a similar trend in virgin oil sensory characteristics when fruit were damaged, resulting from microbiologic degradation of olives and the generation of volatile phenols responsible for off flavors.

Sharp changes in virgin oil characteristics were observed between the control and SDI strategies, with a significant olive oil improvement compared with the SDI treatment. However, the DI treatment had a low impact on oil characteristics, which could be explained by the period of imposed water reduction. In fact, the restricted water supply during the summer, followed by recovering the full crop evapotranspiration during the last steps of lipogenesis and during the ripening period, does not provoke important changes compared with full irrigation, as observed by Berenguer et al. (2006). Our experiment therefore corroborates the usefulness of a DI strategy for water-saving purposes without any effects on olive oil quality compared with the more extensively used full irrigation strategy. However, when irrigation was more restricted (SDI) oil stability increased significantly as a result of a greater phenol content, which explains the greater bitterness, pungency, and astringency reported by the panel, as was also reported by Berenguer et al. (2006) and Tovar et al. (2001). In addition, SDI resulted in a different fatty acid composition, with a greater saturated fatty acid content and a lesser unsaturated and polyunsaturated acid content. Similarly, Serman et al. (2011) observed a lesser MUFA-to-PUFA ratio when water was more restricted. However, controversial results appear in the literature in this respect. For example, Berenguer et al. (2006) reported a lesser polyunsaturated acid content with lower irrigation doses. Their results suggest an effect of strong changes on the MI for some treatments related to severe water restrictions. Similarly, this relationship between restricted irrigation and fatty acid composition contradicts that reported by Dabbou et al. (2011), who worked on 'Koroneiki' and suggested that fatty acid composition is much more affected by maturity than by irrigation dose. In the current study, irrigation restrictions were designed to take into account 
the compromise between oil yield sustainability and quality, and-from this perspective- the effect of changes in MI was negligible.

\section{Conclusions}

Mechanical harvesting tended to damage the fruit, resulting in lower quality virgin olive oil in all cases. The DI strategy (reduction of $75 \%$ of irrigation water from July to September) neither affected fruit nor olive oil characteristics, whereas the SDI strategy (reduction of 75\% from July to September and 30\% from March to June and during October) had a significant effect on olive oil characteristics compared with the control. The overall results show no interaction between harvest system and irrigation strategy, and suggest that in low-yield years, the cumulative effect of mechanical harvesting, deficit irrigation, and fruit maturity influenced oil quality and may explain part of its dramatic decrease. Although the increase of polyphenols and MUFAs can be considered positive for olive oil quality, low yields imply the need for optimization of the SDI strategy if no changes in olive oil quality are desired. Fruit degradation processes, related to oxidation effects, were triggered by mechanical damage and took place in the period immediately after harvest. Thus, two key processes need to be considered: an early harvest and a shortening (as much as possible) of the time between harvesting and fruit processing.

\section{Literature cited}

Alegre, S., J. Marsal, M. Mata, A. Arbonés, J. Girona, and M.J. Tovar. 2002. Regulated deficit irrigation in olive trees Olea europaea L. cv. Arbequina for oil production. Acta Hort. 586:259-262.

Allen, R.G., L.S. Pereira, D. Raes, and M. Smith. 1998. Crop evapotranspiration: Guidelines for computing crop water requirements. FAO Irr. Drainage Paper 56.

Arbonés, A., M. Pascual, and J. Rufat. 2014. Technical and economic analysis of different olive production systems in semiarid regions of the Ebro Valley Spain. Inf. Téc. Econ. Agrar. 110:400-413.

Berenguer, M.J., P.M. Vossen, S.R. Grattan, J.H. Connell, and V.S. Polito. 2006. The irrigation levels for optimum chemical and sensory properties of olive oil. HortScience 41:427-432.
Camposeo, S., G.A. Vivaldi, and C.E. Gattullo. 2013. Ripening indices and harvesting times of different olive cultivars for continuous harvest. Scientia Hort. 151:1-10.

Caporaso, N. 2016. Virgin olive oils: Environmental conditions, agronomical factors and processing technology affecting the chemistry of flavor profile. J. Food Chem. Nanotechnol. 2(1):2131.

Caruso, G., R. Gucci, S. Urbani, S. Esposto, A. Taticchi, I. Di Maio, R. Selvaggini, and M. Servili. 2014. Effect of different irrigation volumes during fruit development on quality of virgin olive oil of cv. Frantoio. Agr. Water Mgt. 134:94103.

Dabbou, S., H. Chehab, F. Brahmi, A. Taticchi, M. Servili, and M. Hammami. 2011. Chemical composition of virgin olive oils from Koroneiki cultivar grown in Tunisia with regard to fruit ripening and irrigation regimes. Intl. J. Food Sci. Technol. 46:577-585.

Dag, A., A. Ben-Gal, U. Yermiahu, L. Basheer, N. Yogev, and Z. Kerem. 2008. The effect of irrigation level and harvest mechanization on virgin olive oil quality in a traditional rain-fed 'Souri' olive orchard converted to irrigation. J. Sci. Food Agr. 88:1524-1528.

Dag, A., S. Boim, Y. Sobotin, and I. Zipori. 2012. Effect of mechanically harvested olive storage temperature and duration on oil quality. HortTechnology 22:528-533.

European Union Standard Methods. 1991. Annexes II and IX in Official Journal European Communities n.L. 248 of 5 Sept., Regulation EEC/2568/91.

Frías, L., A. García-Ortiz, M. Hermoso, A. Jiménez, M.P. Llavero, J. Morales, M.T. Ruano, and M. Uceda. 1991. Analistas de laboratorio de almazara. Junta de Andalucía (ed.). Colección Apuntes N. 6/91: Sevilla.

Girona, J., M. Luna, A. Arbonés, M. Mata, J. Rufat, and J. Marsal. 2002. Young olive trees responses Olea europea, cv Arbequina to different water supplies: Water function determination. Acta Hort. 586:277-280.

Gómez-del-Campo, M., M.A. PérezExpósito, S.B.M. Hammami, A. Centeno, and H.F. Rapoport. 2014. Effect of varied deficit irrigation on components of olive fruit growth and development. Agr. Water Mgt. 137:84-91.

Guerrero, L., A. Romero-Aroca, and J. Tous. 2001. Importance of generalised procrustes analysis in sensory characterisation of virgin olive oil. Food Qual. Prefer. 12(8):515-520.
Hernández, M.L., M.N. Padilla, M. Mancha, and J.M. Martínez-Rivas. 2009. Expression analysis identifies FAD2-2 as the olive oleate desaturase gene mainly responsible for the linoleic acid content in virgin olive oil. J. Agr. Food Chem. 57:6199-6208.

Laübli, W. and P.A. Bruttel. 1986. Determination of the oxidative stability of fats and oils by the 'Rancimat' method. J. Amer. Oil Chem. Soc. 63:792-794.

Morales-Sillero, A. and J.M. García. 2015. Impact assessment of mechanical harvest on fruit physiology and consequences on oil physicochemical and sensory quality from 'Manzanilla de Sevilla' and 'Manzanilla Cacereña' super-highdensity hedgerows: A preliminary study. J. Sci. Food Agr. 95:2445-2453.

Motilva, M.J., M.J. Tovar, M.P. Romero, S. Alegre, and J. Girona. 2000. Influence of regulated deficit irrigation strategies applied to olive trees 'Arbequina' cultivar on oil yield and oil composition during the fruit ripening period. J. Sci. Food Agr. 80:2037-2043.

Palese, A.M., V. Nuzzo, F. Favati, A. Pietrafesa, G. Celano, and C. Xiloyannis. 2010. Effects of water deficit on the vegetative response, yield and oil quality of olive trees Olea europaea L, cv Coratina grown under intensive cultivation. Scientia Hort. 125:222-229.

Romero-Aroca, A., J. Tous, and L. Guerrero. 1999. El análisis sensorial del aceite de oliva virgen, p. 183-197. In: J. Sancho, E. Bota, and J. de Castro (eds.). Introducción al análisis sensorial de los alimentos. Univ. Barcelona, Barcelona, Spain.

Rufat, J., J.M. Villar, M. Pascual, V. Falguera, and A. Arbonés. 2014. Productive and vegetative response to different irrigation and fertilization strategies of an 'Arbequina' olive orchard grown under super-intensive conditions. Agr. Water Mgt. 144:33-41.

Serman, F.V., D. Pacheco, A.O. Pringles, L. Bueno, A. Carelli, and F. Capraro. 2011. Effect of regulated deficit irrigation strategies on productivity, quality and water use efficiency in a high-density 'Arbequina' olive orchard located in an arid region of Argentina. Acta Hort. 888:81-88.

Tovar, M.J., M.J. Motilva, and M.P. Romero. 2001. Changes in the phenolic composition of virgin olive oil from young trees Olea europaea L. cv. Arbequina grown under linear irrigation strategies. J. Agr. Food Chem. 49:5502-5598.

Vázquez-Roncero, A., A. Janer del Valle, and L. Janer del Valle. 1973. Determinación 


\section{Research Reports}

de los polifenoles totales en aceite de oliva. Grasas Aceites 24:350-357.

Vichi, S., A. Romero-Aroca, J. GallardoChacón, J. Tous, E. López-Tamames, and S. Buixaderas. 2009. Influence of olives' storage conditions on the formation of volatile phenols and their role in off-odor formation in the oil. J. Agr. Food Chem. 57:1449-1455.

Vossen, P.M., M.J. Berenguer, S.R. Grattan, J.H. Connell, and V.S. Polito. 2008. The influence of different levels of irrigation on the chemical and sensory properties of olive oil. Acta Hort. 791:439-444.
Yousfi, K., C.M. Weiland, and J.M. Garcia. 2012. Effect of harvesting system and fruit cold storage on virgin olive oil chemical composition and quality of superintensive cultivated 'Arbequina' olives. J. Agr. Food Chem. 60:47434750 . 